\title{
Integrated analysis of gene expression of solute carrier gene SLC19A3 with proven risk factors of microvascular complications in patients with type 2 diabetes
}
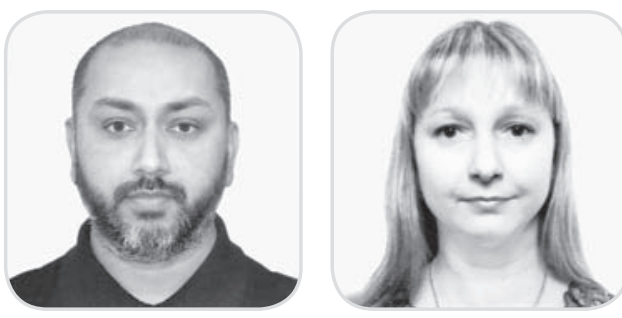

INTRODUCTION

Diabetes mellitus (DM) is a chronic progressive disorder which leads to significant disability, morbidity and is likely to progress to become one of the most widespread conditions worldwide and as an additional burden to the healthcare system already reeling under the effects of the COVID-19 pandemic worldwide. According to the International Diabetes Federation Atlas [1] there are approximately 463 million adults (20-79 years) with diabetes mellitus (DM) and it is expected that by 2045 the figure will rise to 700 million. It is noted that the number of patients is increasing in all the countries [2], but around $79 \%$ of the patients live in middle and low income countries.

The pathogenesis of diabetic microvascular complications is complex and marked by metabolic and vascular factors $[3,4]$. The presence of diabetic polyneuropathy (DPN) in diabetes patients is estimated to be from $6 \%$ to $51 \%$ and depends on various factors such as duration of disease, glycemic control and age [5]. According to published data $50 \%$ of patients can develop a foot ulcer $[6,7]$, and DM is the leading cause of amputation of the limbs [8]. The most common form of DPN is distal symmetric polyneuropathy and consists of large and small fiber neuropathies [9]. It accounts for

\author{
K. Singh, T. Yuzvenko \\ Ukrainian Research and Practical Centre for Endocrine Surgery \\ and Transplantation of Endocrine Organs and Tissues, $\mathrm{MOH}$ of \\ Ukraine, Kyiv
}

$75 \%$ of all diabetic neuropathies. During the course of various studies and their results show that DPN is caused by nerve dysfunction due to oxidative stress and inflammatory factors [10].

There is ever increasing evidence regarding the risk factors of DPN in diabetes patients, such as age, duration of disease, obesity, smoking, and presence of chronic kidney disease in patients with type $2 \mathrm{DM}$ and the effect of these risk factors in the progression of DPN.

The treatment of diabetic polyneuropathy is generally supportive and targets the prevention of progression of the disease and its complications. Short term tight glycemic control has not been shown to effectively decrease symptoms of DPN in patients with DM. Results of some studies have shown positive results for treatment of painful peripheral neuropathy [11]. Generally, the recommendations for treatment of DPN are targeted for the relief of symptoms of neuropathy, but current treatment patterns and practices are inconsistent and do not addresses the pathways involved in the pathophysiology of diabetic microvascular complications. Taking into consideration the metabolic pathways involved in the complications of DM, antioxidants are a treatment option [12], which 
needs to be further studied. In published data, there is information regarding the effects of benfothiamine, but its effect in the enhancement of the adaptive regulatory response of the expression of THTR- 2 have not been elucidated and very little information is available.

Therefore, in-depth study of the frequency and the risk factors for the development of DPN in patients with type 2 DM, development of new diagnostic tool for precise, quick and easy assessment of patients with DPN is a promising area, and the use of novel drugs, addressing the pathogenetic mechanisms involved in the progression of DPN is of great practical importance.

The solute carrier (SLC) group of membrane transport proteins include over 400 members organized into 65 families [13]. Most members of the SLC group are located in the cell membrane, but some are located in the mitochondria. The SLC families include genes that encode passive transporters, ion transporters, and exchangers. The different SLC families are functionally related to each other and generally rely on an ion gradient over the cell membrane as the driving force for transportation, but with a few exceptions [14]. The transport protein SLC19A3 (THTR2) is associated with the plasma membrane, mediates the transport of extracellular thiamin into the cytosol. Changes in gene expression by factors such as age has been studied only in animal models $[15,16]$. In the body the transporter is widely distributed and is consistent with its involvement in thiamin uptake [17]. Very little data is available regarding the expression of thiamine transporter proteins in diabetic patients with DPN, but data regarding the role of THTR-2 and its expression in the intestine and kidneys is available [18].

Objective - to study the correlative variation in gene expression of SLC19A3 in type 2 diabetes patients with proven risk factors of diabetes complications.

\section{MATERIALS AND METHODS}

In the study, 190 patients with type 2 DM were screened for diabetic peripheral neuropathy (DPN). DPN was confirmed in $(n=105)$ patients displaying symptoms of diabetic polyneuropathy with the involvement of small nerve fibers and large nerve fibers. Out of the total cohort, 45 patients with type 2 DM were shortlisted and randomized according to the severity of diabetic polyneuropathy, for assessment of the expression of the gene SLC19A3 in stage 1 of the gene expression study.

The patients were divided into three categories depending upon the severity of DPN. Patients in group $1(n=15)$ had a positive DNS score, positive 5.07$10.00 \mathrm{~g}$ monofilament test for testing protective sensory loss and a VPT of $16-25$ Vindicating stage 1 DPN. Patients in group $2(n=15)$ had a positive DNS score, positive 5.07-10.00 g monofilament test and a VPT of $26-35 \mathrm{~V}$ indicating stage 2 DPN. Patients in group 3 (control) $(n=15)$ had a positive DNS score but with negative $5.07-10.00 \mathrm{~g}$ monofilament test and a normal VPT value of $01-15 \mathrm{~V}$. The patients enlisted for gene expression analysis in different categories of patients did not have any significant difference and statistical variations in the blood tests and the anthropometric data (Table 1).

All the patients included in the gene expression analysis were of white European ancestry (Caucasian), which in theory corresponds to the Hardy-Weinberg principle of allele and genotype frequencies in a population.

Gene expression analysis of SLC19A3 was examined by RT-qPCR, the material for gene expression testing was the mRNA. The mRNA was extracted from the leucocytes in the peripheral blood of the patients. Extraction and reverse transcription was done with the commercially available SuperScript VILO cDNA Synthesis Kit. It allows to generate the first strand of cDNA for two step RT-qPCR application. The procedure was done according to the procedure recommendations provided by the manufacturer. The next step involved the amplification of DNA in qPCR. In the process TaqMan Fast Advanced Master Mix was used, it contains AmpliTaq Fast DNA Polymerase, uracil-N-glycosylase (UNG), dNTPs with dUTP, ROX dye (passive reference), and optimized buffer components. The primers used for SLC19A3 gene expression were: Forward, 5'-TTCTCC ATGATGAGACCCTC and Reverse, 5'-ATGATGACTGGCTTG TAGCG. The SLC19A3 TaqMan Gene Expression Assay was used to evaluate the gene expression in the samples for the target gene. The expression levels of SLC19A3 mRNA were normalized to glyceraldehyde-3phosphate dehydrogenase (GAPDH). Fold change of

DNS and VPT values of patients in different groups

\begin{tabular}{|l|l|l|l|}
\hline $\begin{array}{l}\text { DPN } \\
\text { assessment }\end{array}$ & $\begin{array}{l}\text { Group 1 } \\
\text { (Grade 1 } \\
\text { VPT loss), } \\
\mathrm{n}=15\end{array}$ & $\begin{array}{l}\text { Group 2 } \\
\text { (Grade 2 } \\
\text { VPT loss), } \\
\mathrm{n}=15\end{array}$ & $\begin{array}{l}\text { Group 3 } \\
\mathrm{n}=15\end{array}$ \\
\hline DNS & $1-3$ & $2-4$ & $1-2$ \\
\hline VPT & $17-25 \mathrm{~V}$ & $26-34 \mathrm{~V}$ & $6-11 \mathrm{~V}$ \\
\hline
\end{tabular}


SLC19A3 expression was calculated by the equation $2-\Delta \Delta C t$. $\Delta C t$ was calculated by subtracting the $\mathrm{Ct}$ values of GAPDH from the $\mathrm{Ct}$ values of SLC19A3. The expression of the gene SLC19A3 was done initially before therapy and after benfothiamine therapy in the patients in stage 2 of the study.

\section{RESULTS AND DISCUSSION}

Analysis of SLC19A3 gene expression in patients with type 2 diabetes. In the initial phase (stage 1) of our investigation samples were collected from 45 patients to check the gene expression of the target gene (SLC19A3). The expression levels of SLC19A3 mRNA were normalized to glyceraldehyde-3-phosphate dehydrogenase (GAPDH) (Table 2).

It is evident that the $C_{T}$ value of the target gene (SLC19A3) in all the three groups in comparison to each other did not have significant difference in the initial phase of the investigation, the difference in expression of SLC19A3 in the groups was $\pm 2.65 \%$. In group $1\left(C_{T}-26.2667 \pm 0.6520\right)$ and group $3\left(C_{T}-26.6667 \pm\right.$ $0.7080)$ the $C_{T}$ values for SLC19A3 were quite similar and the expression was more abundant as compared to group $2\left(C_{T}-26.7333 \pm 0.5380\right)$ where the $C_{T}$ value was higher. The scenario for GAPDH was also quite similar to the trend as in the target gene, in group 1 $\left(C_{T}-20.0714 \pm 0.6990\right)$ and group $3\left(C_{T}-19.8667 \pm\right.$ $\pm 0.8640)$ the $C_{T}$ value for GAPDH was lower, whereas the $C_{T}$ value in group $2\left(C_{T}-20.9333 \pm 0.5380\right)$ was higher, meaning that the expression was less abundant as compared to the other two groups in the study. The $\Delta C_{T}$ $\mu$ (mean) for group 1 (with grade 1 VPT loss) was 6,1333 ( $p<0.05)$. The $\Delta C_{T} \mu$ (mean) for group 2 (with grade 2 VPT loss) was 5.80 ( $p<0.05)$. The $\Delta C_{T} \mu$ (mean) for group 3 was $6.8(p<0.05)$ (Figure).

The variability of $C_{T}$ values SLC19A3 and GAPDH in correlation to $\mathrm{HbA} 1 \mathrm{c}$ in patients with type 2 diabetes in study groups

Group 1. The $C_{T}$ values for $S L C 19 A 3$ in the patients with $\mathrm{HbA} 1 \mathrm{c}<7.5 \%(25.800 \pm 0.656( \pm 2.54 \%))$ and patients with $\mathrm{HbA} 1 \mathrm{c} 7.6-8-9 \%\left(\mathrm{C}_{\mathrm{T}}-25.800 \pm 1.022\right.$ $( \pm 3.96 \%))$ the $C_{T}$ values were quite similar and the expression was more abundant as compared to patients with $\mathrm{HbA} 1 \mathrm{c}>9.0 \%\left(C_{T}-27.200 \pm 1.163( \pm 4.28 \%)\right)$ where the $C_{T}$ value was higher. The scenario for GAPDH was also quite similar to the trend as in the target gene patients with $\mathrm{HbA} 1 \mathrm{c}<7.5 \%\left(\mathrm{C}_{\mathrm{T}}-19.600 \pm 1.052\right.$ $( \pm 5.37 \%))$ and patients with $\mathrm{HbA} 1 \mathrm{c} 7.6-8-9 \%\left(\mathrm{C}_{\mathrm{T}}-\right.$ $19.600 \pm 1.052( \pm 5.37 \%))$ the $C_{T}$ value for GAPDH was lower, whereas the $C_{T}$ value in patients with $\mathrm{HbA} 1 \mathrm{c}$ >
Table 2

Gene expression $C_{T}$ values of Target gene

\begin{tabular}{|c|c|c|c|}
\hline Gene & $\begin{array}{l}\text { Group } 1 \\
\text { (Grade } 1 \\
\text { VPT loss), } \\
\mathrm{n}=15\end{array}$ & $\begin{array}{l}\text { Group } 2 \\
\text { (Grade } 2 \\
\text { VPT loss), } \\
n=15\end{array}$ & $\begin{array}{l}\text { Group 3, } \\
n=15\end{array}$ \\
\hline $\begin{array}{l}\text { SLC19A3 } \\
\text { Stage } 1\end{array}$ & $\begin{array}{l}26.2667 \pm \\
0.6520\end{array}$ & $\begin{array}{l}26.7333 \pm \\
0.5380\end{array}$ & $\begin{array}{l}26.6667 \pm \\
0.7080\end{array}$ \\
\hline $\begin{array}{l}\text { GAPDH } \\
\text { Stage } 1\end{array}$ & $\begin{array}{l}20.0714 \pm \\
0.6990\end{array}$ & $\begin{array}{l}20.9333 \pm \\
0.5380\end{array}$ & $\begin{array}{l}19.8667 \pm \\
0.8640\end{array}$ \\
\hline
\end{tabular}

$9.0 \%\left(C_{T}-21.200 \pm 0.656( \pm 3.09 \%)\right)$ was higher, meaning that the expression was less abundant as compared to the patients with $\mathrm{HbA} 1 \mathrm{c}<8.9 \%$. The $\Delta \mathrm{C}_{\mathrm{T}}$ $\mu$ (mean) for patients with $\mathrm{HbA} 1 \mathrm{c}<7.5 \%$ was 6.2 . The $\Delta \mathrm{C}_{\mathrm{T}} \mu$ (mean) for patients with $\mathrm{HbA1c} 7.6-8.9 \%$ was 6.2. The $\Delta \mathrm{C}_{\mathrm{T}} \mu$ (mean) for patients with $\mathrm{HbA1C}>9.0 \%$ was 6.0.

Group 2. The $C_{T}$ values for $S L C 19 A 3$ in the patients with $\mathrm{HbA} 1 \mathrm{c}<7.5 \%(26.400 \pm 0.894( \pm 3.39 \%))$ and patients with $\mathrm{HbA} 1 \mathrm{c} 7.6-8-9 \%\left(\mathrm{C}_{\mathrm{T}}-26.200 \pm 0.656\right.$ $( \pm 2.50 \%)$ ) the $C_{T}$ values were quite similar and the expression was more abundant as compared to patients with $\mathrm{HbA1C}>9.0 \%\left(C_{T}-27.600 \pm 0.701( \pm 2.54 \%)\right)$ where the $C_{T}$ value was slightly higher. In the case of GAPDH the trend was also quite similar to the target gene in patients with $\mathrm{HbA} 1 \mathrm{c}<7.5 \%\left(C_{T}-20.800 \pm\right.$ $\pm 0.656( \pm 3.15 \%))$ and patients with $\mathrm{HbA1c} 7.6-8-$ $9 \%(C T-20.600 \pm 0.701( \pm 3.40 \%))$ the $C_{T}$ value for GAPDH was lower, whereas the $C_{T}$ value in patients with $\mathrm{HbA} 1 \mathrm{C}>9.0 \%\left(\mathrm{C}_{\mathrm{T}}-21.400 \pm 1.189( \pm 5.56 \%)\right)$ was higher, meaning that the expression was slightly less profound as compared to the patients with $\mathrm{HbA} 1 \mathrm{c}$

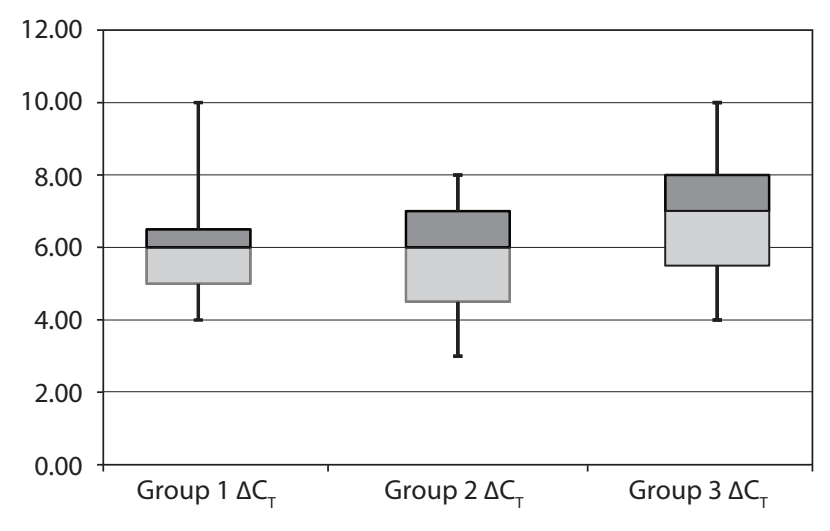

Figure. Box Plot - Comparative analysis of changes in $\Delta C_{T}$ in patients before treatment with benfothiamine. The boxes mark the interval between the $25^{\text {th }}$ and $75^{\text {th }}$ percentiles. The whiskers denote the interval between the $10^{\text {th }}$ and $90^{\text {th }}$ percentiles 
of $<7.5 \%$ and $\mathrm{HbA} 1 \mathrm{c}$ of $7.6-8,9 \%$. The $\Delta \mathrm{C}_{\mathrm{T}} \mu$ (mean) for patients with $\mathrm{HbA} 1 \mathrm{c}<7.5 \%$ was 5.6. The $\Delta \mathrm{C}_{\mathrm{T}} \mu$ (mean) for patients with $\mathrm{HbA} 1 \mathrm{c} 7.6-8.9 \%$ was 5.6. The $\Delta \mathrm{C}_{\mathrm{T}} \mu$ (mean) for patients with $\mathrm{HbA} 1 \mathrm{c}>9.0 \%$ was 6.2 .

Group 3. The $C_{T}$ values for SLC19A3 in the patients with $\mathrm{HbA} 1 \mathrm{c}<7.5 \%(26.000 \pm 1.240( \pm 4.77 \%))$ and patients with $\mathrm{HbA} 1 \mathrm{c} 7.6-8-9 \%\left(\mathrm{C}_{\mathrm{T}}-26.400 \pm 0.894\right.$ $( \pm 3.39 \%))$ the $C_{T}$ values were quite similar and the expression was more abundant as compared to patients with $\mathrm{HbA} 1 \mathrm{C}>9.0 \%\left(\mathrm{C}_{\mathrm{T}}-27.600 \pm 1.052( \pm 3.81 \%)\right)$ where the $C_{T}$ value was slightly higher. This trend was seen in all the groups, that $C_{T}$ value had a tendency to increase in patients with high levels of $\mathrm{HbA} 1 \mathrm{c}$. In the case of GAPDH the trend was also quite similar to the target gene in patients with $\mathrm{HbA} 1 \mathrm{c}<7.5 \%\left(\mathrm{C}_{\mathrm{T}}-\right.$ $19.000 \pm 1.839( \pm 9.68 \%))$ and patients with $\mathrm{HbA} 1 \mathrm{c}$ $7.6-8-9 \%\left(C_{T}-19.6 \pm 0.894( \pm 4.56 \%)\right)$ the $C_{T}$ value for GAPDH was lower, whereas the $C_{T}$ value in patients with $\mathrm{HbA} 1 \mathrm{C}>9.0 \%\left(C_{T}-21.000 \pm 0.96( \pm 4.57 \%)\right)$ was higher, meaning that the expression was slightly less profound as compared to the patients with HBA1c of $<$ $7.5 \%$ and $\mathrm{HbA} 1 \mathrm{c}$ of $7.6-8.9 \%$. The $\Delta \mathrm{C}_{\mathrm{T}} \mu$ (mean) for patients with $\mathrm{HbA} 1 \mathrm{c}<7.5 \%$ was 7.0. The $\Delta \mathrm{C}_{\mathrm{T}} \mu$ (mean) for patients with $\mathrm{HbA} 1 \mathrm{c} 7.6-8.9 \%$ was 6.8. The $\Delta \mathrm{C}_{\mathrm{T}} \mu$ (mean) for patients with $\mathrm{HbA} 1 \mathrm{c}>9.0 \%$ was 6.6.

The variability of $C_{T}$ values SLC19A3 and GAPDH in correlation to duration of disease in patients with type 2 diabetes

Group 1. The $C_{T}$ values for $S L C 19 A 3$ in the patients with duration of disease $<7$ years $\left(C_{T}-25.8571 \pm\right.$ $\pm 0.8330( \pm 3.22 \%)$ ) was slightly less as compared to patients with duration of disease $7-10$ years $\left(C_{T}-26.625 \pm 0.913( \pm 3.43 \%)\right)$. The difference in $\mathrm{C}_{\mathrm{T}}$ values was not significant. For GAPDH there was no significant difference between the two categories. In patients with duration of disease $<7$ years $\left(C_{T}-\right.$ $20.1429 \pm 1.004( \pm 4.98 \%))$ was almost identical to the $\mathrm{C}_{\mathrm{T}}$ value of patients with duration of disease $7-$ 10 years $\left(C_{T}-20.125 \pm 0.879( \pm 4.37 \%)\right)$. The $\Delta C_{T} \mu$ (mean) for patients with duration of disease $<7$ years was 5.71. The $\Delta C_{T} \mu$ (mean) for patients duration of disease $7-10$ years was 6.5 .

Group 2. The $C_{T}$ values for $S L C 19 A 3$ in the patients with duration of disease $<7$ years $\left(C_{T}-26.200 \pm 0.656\right.$ $( \pm 2.50 \%))$ and in patients with duration of disease $>10$ years $\left(C_{T}-26.600 \pm 0.894( \pm 3.36 \%)\right)$ was less as compared to patients with duration of disease 7 10 years $\left(C_{T}-27.400 \pm 0.894( \pm 3.26 \%)\right)$. The difference in $C_{T}$ values between the categories representing duration of disease did not show any statistical valid trend. For GAPDH in patients with duration of disease $<7$ years $\left(C_{T} \quad 20.600 \pm 1.052( \pm 5.11 \%)\right)$ and in patients with duration of disease $>10$ years $\left(C_{T}-20.800 \pm\right.$ $\pm 0.656( \pm 3.15 \%)$ ) was less as compared to the $C_{T}$ value in patients with duration of disease $7-10$ years $\left(C_{T}\right.$ $21.400 \pm 0.894( \pm 4.18 \%))$. The difference in $C_{T}$ values in the categories of duration of disease indicated that gene expression of the target gene and the normalizing gene in group 2 was independent of the duration of disease. The $\Delta C_{T} \mu$ (mean) for patients with duration of disease $<7$ years was 5.6. The $\Delta C_{T} \mu$ (mean) for patients duration of disease 7-10 years was 6.0. The $\Delta C_{T}$ $\mu$ (mean) for patients duration of disease $>10$ years was 5.8.

Group 3 (control). The $C_{T}$ values for SLC19A3 in the patients with duration of disease $<7$ years $\left(C_{T}-26.00 \pm\right.$ $\pm 0.97( \pm 3.73 \%))$ and inpatients with duration of disease $>10$ years $\left(C_{T}-27.000 \pm 1.386( \pm 5.13 \%)\right)$ was less as compared to patients with duration of disease $7-10$ years $\left(C_{T}-27.3333 \pm 0.9980( \pm 3.65 \%)\right)$. The difference in $C_{T}$ values between the categories representing duration of disease did not show any statistical valid trend. For GAPDH in patients with duration of disease $<7$ years $\left(C_{T}-19.1429 \pm 1.3390\right.$ $( \pm 6.99 \%))$ the $C_{T}$ value was less as compared to the patients with duration of disease $>10$ years $\left(C_{T}\right.$ $20.500 \pm 0.693( \pm 3.38 \%))$ and duration of disease $7-10\left(C_{T}-20.5 \pm 1.2( \pm 5.85 \%)\right)$. The difference in $C_{T}$ values in the categories of duration of disease indicated that gene expression of the target gene and the normalizing gene in group 3 was independent of the duration of disease. The $\Delta C_{T} \mu$ (mean) for patients with duration of disease $<7$ years was 6.8. The $\Delta C_{T} \mu$ (mean) for patients duration of disease $7-10$ years was 6.8. The $\Delta C_{T} \mu$ (mean) for patients duration of disease $>10$ years was 6.5 .

\section{CONCLUSIONS}

In the first stage of the study in patients with type 2 diabetes with diabetic polyneuropathy with the involvement of small nerve fibers and large nerve fibers we found that the difference in expression of the solute carrier gene SLC19A3 in patients with variable levels of neuropathy was not significant. As evident from the $C_{T}$ values and the value of $\Delta C_{T}$ there was no statistically valid difference between the groups. The $C_{T}$ value of the target gene (SLC19A3) in all the three groups, in comparison to each other did not have significant difference in the initial phase of the investigation, the difference in expression of SLC19A3 in the groups was $\pm 2.65 \%$. In correlation to 
duration of disease the trend was similar, showing that duration of disease does not play an altering role in the expression of the target gene. In correlation to risk factor glycemic control (level of HbA1c) the expression of the target gene was slightly more profound in patients with an $\mathrm{HbA1c}$ of $<8.9 \%$ as compared to the patients with $\mathrm{HbA} 1 \mathrm{c}$ value $9.0 \%$. Taking into consideration the results of the study it can be stated the expression of SLC19A3 is independent of the severity of diabetic polyneuropathy, duration of diabetes and the glycemic compensation in patients with type 2 diabetes.

Authors' contributions. K. Singh and Yuzvenko $T$. participated in the conception and design of the study. All authors took part in the collection and analyses of the data. $K$ Singh drafted the initial manuscript and Yuzvenko $T$ revised the manuscript. All authors read and approved the final manuscript.

Competing interests. The authors declare that they have no competing interests.

Ethics approval and consent to participate. This study conformed to the guidelines of the Declaration of Helsinki, and the study procedures were reviewed and approved by the medical research ethics committee Each patient agreed to participate and signed the informed consent form.

Funding. The study was self funded.

\section{REFERENCES}

1. Sarwar N, Gao P, Seshasai SR. et al. Emerging Risk Factors Collaboration. Diabetes mellitus, fasting blood glucose concentration, and risk of vascular disease: a collaborative meta-analysis of 102 prospective studies. Lancet. 2010; 26;375:2215-22. doi: 10.1016/S01406736(10)60484-9.

2. Kaiser N, Sasson S, Feener EP. et al. Differential regulation of glucose transport and transporters by glucose in vascular endothelial and smooth muscle cells. Diabetes. 1993;42:80-9. doi:10.2337/diab.42.1.80

3. Heilig CW, Concepcion LA, Riser BL. et al. Overexpression of glucose transporters in rat mesangial cells cultured in a normal glucose milieu mimics the diabetic phenotype. J Clin Invest. 1995;96:1802-14. doi:10.1172/JCI1 18226

4. Brownlee M. The pathobiology of diabetic complications, a unifying mechanism. Diabetes. 2005;54(6):1615-25. doi:10.2337/diabetes.54.6.1615

5. Fowler MJ. Microvascular and macrovascular complications of diabetes. clinical diabetes. 2008;26(2):77-82. doi: 0.2337/diaclin.26.2.77

6. Du XL, Edelstein D, Rossetti L. et al. Hyperglycemiainduced mitochondrial superoxide overproductionactivates the hexosamine pathway and induces plasminogen activator inhibitor-1 expression by increasing Sp1 glycosylation. Proc Natl Acad Sci U S A. 2000;97:12222-6. doi:10.1073/pnas.97.22.12222

7. Dyck PJ, Kratz KM, Karnes JL. et al. The prevalence by staged severity of various types of diabetic neuropathy, retinopathy, and nephropathy in a population-based cohort: the Rochester Diabetic Neuropathy Study. Neurology 1993;43:817-24. doi:10.1212/wnl.43.4.817

8. Tesfaye SL, Boulton AJ, Dyck PJ. et al. Diabetic neuropathies: update on definitions, diagnostic criteria and estimation of severity (The Toronto Expert Group Meeting 2009). Diabetes Care 2010;33(10):2285-93. doi: 10.2337/dc10-1303.

9. Vamos EP, Bottle A, Edmonds ME, Valabhji J, Majeed A, Millett $C$. Trends in lower extremity amputations in people with and without diabetes in England. 19962005. Diabetes Res Clin Pract 2010;87(2):275-82. doi: 10.1016/j.diabres.2009.11.016.

10. Singh N, Armstrong DG, Lipsky BA. Preventing foot ulcers in patients with diabetes. JAMA 2005;293:217-28. doi:10.1001/jama.293.2.217.

11. Llewelyn JG, Tomlinson DR, Thomas PK. Diabetic Neuropathies. In: Dyck PJ, Thomas, PK, eds. Peripheral Neuropathy. 4th ed. Philadelphia: Elsevier; 2005:19511992. ISBN: 9780721694917.

12. Selvarajah D, Wilkinson ID, Maxwell M. et al. Magnetic resonance neuroimaging study of brain structural differences in diabetic peripheral neuropathy. Diabetes Care. 2014;37(6):1681-8. doi: 10.2337/dc13-2610.

13. Ebata-Kogure N, Nozawa K, Murakami A, Toyoda T, Haga Y, Fujii K. Clinical and economic burdens experienced by patients with painful diabetic peripheral neuropathy: An observational study using a Japanese claims database. PLoS One. 2017;12(10):e0187250. doi: 1371/journal.pone.0187250.

14. Clinical practice. Diabetic sensory and motor neuropathy. N Engl J Med. 2016. vinikai. doi: 10.1056/ NEJMx160009.

15. Dyck PJ. Severity and staging of diabetic polyneuropathy. In: Gries FA, Cameron NE, Low PA, Ziegler D, eds. Textbook of Diabetic Neuropathy. Stuttgart: Thieme; 2003. P. 170-175. doi:1007/978-81-322-2635-2.

16. Dyck PJ, Overland CJ, Low PA. et al. Signs and symptoms versus nerve conduction studies to diagnose diabetic sensorimotor polyneuropathy: $\mathrm{Cl}$ vs. NPhys trial. Muscle Nerve. 2011;42:157-64. doi: 10.1002/mus.21661.

17. Boulton AJM, Malik RA, Arezzo JC, Sosensko JM. Diabetic Somatic neuropathies. Technical Review. Diabetes Care 2004;27(6):1458-78. doi:10.2337/diacare.27.6.1458 
18. Boulton AJ, Vinik Al, Arezzo JC. et al. Diabetic neuropathies: a statement by the American Diabetes Association. Diabetes Care. 2005;28:956-62.

\[ \text { ABSTRACT } \]
Integrated analysis of gene expression
of solute carrier gene SLC19A3 with proven risk
factors of microvascular complications in patients
with type 2 diabetes

\section{K. Singh, T. Yu. Yuzvenko}

Ukrainian Research and Practical Centre for Endocrine Surgery and Transplantation of Endocrine Organs and Tissues, $\mathrm{MOH}$ of Ukraine, Kyiv

Diabetes mellitus (DM) is a chronic progressive disorder which leads to significant disability, morbidity and is likely to progress to become one of the most widespread conditions worldwide and as an additional burden to the healthcare system already reeling under the effects of the COVID-19 pandemic worldwide.

Aim - to study the correlative variation in gene expression of SLC19A3 in type 2 diabetes patients with proven risk factors of diabetes complications.

Materials and methods. In the study, 190 patients with type 2 DM were screened for diabetic peripheral neuropathy (DPN). DPN was confirmed in $(n=105)$ patients displaying symptoms of diabetic polyneuropathy with the involvement of small nerve fibers and large nerve fibers. Out of the total cohort, 45 patients with type 2 DM were shortlisted and randomized according to the severity of diabetic polyneuropathy, for assessment of the expression of the gene SLC19A3 in stage 1 of the gene expression study.

Results. In the first stage of the study in patients with type 2 diabetes with diabetic polyneuropathy with the involvement of small nerve fibers and large nerve fibers we found that the difference in expression of the solute carrier gene SLC19A3 in patients with variable levels of neuropathy was not significant. As evident from the $C_{T}$ values and the value of $\Delta C_{T}$ there was no statistically valid difference between the groups. The $C_{T}$ value of the target gene (SLC19A3) in all the three groups, in comparison to each other did not have significant difference in the initial phase of the investigation. In correlation to duration of disease the trend was similar, showing that duration of disease does not play an altering role in the expression of the target gene. In correlation to risk factor glycemic control (level of $\mathrm{HbA} 1 \mathrm{c}$ ) the expression of the target gene was slightly more profound in patients with an $\mathrm{HbA} 1 \mathrm{c}$ of $<8.9 \%$ as compared to the patients with $\mathrm{HbA} 1 \mathrm{c}$ value $>9.0 \%$.

Conclusions. Taking into consideration the results of the study it can be stated the expression of SLC19A3 is independent of the severity of diabetic polyneuropathy, duration of diabetes and the glycemic compensation in patients with type 2 diabetes.

Keywords: type 2 diabetesmellitus, microvascular complications, expression of solute carrier gene SLC19A3.

\section{PEЗЮME}

Комплексний аналіз експресії гена SLC19A3 у хворих на цукровий діабет 2-го типу з факторами ризику мікросудинних ускладнень

\section{Сінгх Канварджіт, Т. Ю. Юзвенко}

Український науково-практичний центр ендокринної хірургії та трансплантації ендокринних органів і тканин МОЗ України, Київ

Цукровий діабет (ЦД) - це хронічна патологія, котра прогресує і призводить до значної втрати працездатності, росту захворюваності та додаткового навантаження на систему охорони здоров'я.

Мета - вивчити кореляційні варіації експресії гена SLC19A3 у хворих на ЦД 2 типу з чинниками ризику діабетичних ускладнень.

Матеріали та методи. Проведено обстеження 190 пацієнтів із ЦД 2 типу на наявність діабетичної периферичної нейропатії (ДПН). У 105 пацієнтів, які мали симптоми діабетичної полінейропатії із залученням дрібних та великих нервових волокон, наявність ДПН підтверджено. Із загальної когорти 45 пацієнтів із ЦД 2 типу були рандомізовані відповідно до тяжкості діабетичної полінейропатії для оцінки експресії гена SLC19A3.

Результати. На першому етапі дослідження у пацієнтів 3 цукровим діабетом 2 типу з діабетичною полінейропатією з залученням дрібних і великих нервових волокон ми виявили, що різниця в експресії гена SLC19A3 була несуттєвою. Очевидно, що в значеннях $C_{T}$ і значеннях $\Delta C_{T}$ статистично достовірної різниці між групами не було. Значення $C_{T}$ цільового гена (SLC19A3) в усіх трьох групах один з одним не мали істотної різниці в початковій фазі дослідження. В кореляції фактора ризику, такого як тривалість захворювання, тенденція була аналогічною, показуючи, що тривалість хвороби не відіграє ролі в зміні експресії гена. В кореляції фактора ризику за 
рівнем глікованого гемоглобіну - експресія гена була трохи більшою у пацієнтів $3 \mathrm{HbA1c}<8,9 \%$ порівняно із пацієнтами з значенням $\mathrm{HbA1c}>9,0 \%$.

Висновки. Беручи до уваги результати дослідження можна констатувати, що експресія гена SLC19A3 не залежить від ступеня тяжкості діабетичної полінейропатії, тривалості цукрового діабету i компенсації глікемії у пацієнтів з цукровим діабетом 2 типу.

Ключові слова: цукровий діабет 2 типу, мікросудинні ускладнення, експресія гена розчинного носія SLC19A3.

\section{PEЗЮME}

Комплексный анализ экспрессии гена SLC19A3 у больных с сахарным диабетом 2 типа с факторами риска микрососудистых осложнений Сингх Канварджит, Т. Ю. Юзвенко

Украинский научно-практический центр эндокринной хирургии и трансплантации эндокринных органов и тканей МЗ Украины, Киев

Сахарный диабет (СД) - это хроническая патология, которая прогрессирует и приводит к значительной потере трудоспособности, росту заболеваемости и дополнительной нагрузке на систему здравоохранения.

Цель - изучить корреляционные вариации экспрессии гена SLC19A3 у больных с сахарным диабетом 2 типа с факторами риска диабетических осложнений.

Материалы и методы. Проведено обследование 190 пациентов с СД 2 типа на наличие диабетической периферической нейропатии (ДПН).У 105 пациентов, имевших симптомы диабетической полинейропатии с вовлечением мелких и крупных нервных волокон, наличие ДПН подтверждено. Из общей когорты 45 пациентов с СД 2 типа были рандомизированы в соответствии с тяжестью диабетической полинейропатии для оценки экспрессии гена SLC19A3.

Результаты. На первом этапе исследования у пациентов с сахарным диабетом 2 типа с диабетической полинейропатией с вовлечением мелких и крупных нервных волокон мы обнаружили, что разница в экспрессии гена-носителя SLC19A3 была незначительна. Очевидно, что в значениях $C_{T}$ значениях $\Delta \mathrm{C}_{\mathrm{T}}$ статистически достоверной разницы

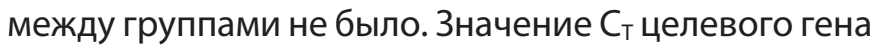
(SLC19A3) во всех трех группах по сравнению друг с другом не имели существенной разницы в начальной фазе исследования. В корреляции фактора риска, такой как продолжительность заболевания, тенденция была аналогичной, показывая, что продолжительность болезни не играет изменяющей роли в выражении экспрессии гена. В корреляции фактора риска по результатам гликированного гемоглобина - экспрессия гена была незначительно больше у пациентов с HbA1c < 8,9 \% по сравнению с пациентами со значением $\mathrm{HbA1c}>9,0 \%$.

Выводы. Принимая во внимание результаты исследования можно констатировать, что экспрессия гена SLC19A3 не зависит от степени тяжести диабетической полинейропатии, продолжительности сахарного диабета и компенсации гликемии у пациентов с сахарным диабетом 2 типа.

Ключевые слова: сахарный диабет 2 типа, микрососудистые осложнения, экспрессия гена раастворимого носителя SLC19A3.

Дата надходження до редакції 04.05.2021 p.

Дата рецензування 19.05.2021 p.

Дата nidnucy cmammi до друку 31.05.2021 p. 